\title{
Editorial:
}

\section{Pension Questions that Are Politically Out-of-the-Question}

It has been the tradition that the editor of each section of the Canadian Journal on Aging takes a turn at the end of his/her term to hold a special symposium at the annual Scientific and Educational Meetings of the Canadian Association on Gerontology. This edition of the Canadian Journal on Aging is an outcome of the symposium entitled Re-Writing Social Policy in an Aging Society held in Vancouver in October 1995 and funded by Health Canada. The goals of the symposium were threefold, to examine the range of proposed changes to social security, such as raising the age of retirement; to explore how these changes might affect the health and well-being of seniors, and to explore these issues within an international context.

At first glance, it is tempting to consider the symposium as old news. After all, the Seniors Benefit has been proposed and the Canada Pension Plan consultations are over, with preordained recommendations sure to follow. The reduction of the debt and the deficit, the mantra of the moment, has insured that cuts to public pensions have been carefully measured and politically appraised. What more could be said?

This question is the question. Plenty could be said, but there seems to be a pervasive silence across the gerontological landscape. Muted by the need to be fiscally responsible, Canadians seem to believe they are at the mercy of the economic imperative. With the best of intentions, those few who do address the proposed changes to the pension system almost always preface their remarks with an acknowledgment of the pressing urgency of the fiscal crisis and then proceed to fill in the blanks with half-hearted changes designed to keep program costs contained. Indeed, they are highly unlikely to move beyond the false parameters for debt reduction prescribed by the Department of Finance and the international money markets - cutting the cost of social programs - even though most economists know there are other options available (Freeman, 1995; Osberg \& Fortin, 1996). Failing to question national fiscal and monetary policy for fear that the "money markets will be made nervous" is what we have come to passively accept - almost a type of apocalyptic economics. We have somehow forgotten, for example, certain facts, such as that those in charge of the money markets are responsible for making a profit for their clients, often at the expense of the public good (Van Audenrode, 1996).

What is suggested here is not necessarily a conspiracy theory that "we have been had" by an outpouring of conservative analyses and propaganda (Freeman, 1995, p. 253), but rather that we are in danger of losing our self-assurance to "... criticize, to reject conformity, passivity and inevitability," the normal expectations of any citizen living in a democracy (Saul, 
1995, p. 36). It would be in our own best interests (most of us will retire), not to mention the focus of our enterprise - older people, to ask questions and think critically about the changes being made to social security; these changes are based on the exigencies of today, which, in all probability, will become outmoded tomorrow. The papers in this issue raise important questions about our collective vision of our social security system and the type of moral economy we will have in the future. The moral economy pertains to the shared assumptions about what constitutes a fair exchange in our society, such as who is entitled to ask for aid and when, and circumstances obligating the privileged to provide aid (Stone, 1984). As an analytical tool, the moral economy helps to clarify how we are moving from a society based on use value, that is, one that attempts to maximize the possibilities of a decent life for all, to one of exchange value, based solely on economic indicators as the measure of the public good (Hendricks \& Leedham, 1991).

Starting with an international perspective, Anne-Marie Guillemard explains how the topography of the life course has changed and how social policy misses the mark as a result. Piecemeal tinkering with the pension system to counter unemployment has produced structural changes that cannot be easily reversed. Early retirement is firmly entrenched, employers view older workers as obsolete, and older workers themselves have accepted these views and plan their lives around leaving the labour force early. Pension reform, implemented in isolation from other aspects of the social security system, produces many unintended consequences and precludes interspersing socially meaningful reforms across the life-span. Social policy based on the disappearing tripartite view of the life course (school, work, retirement) is an anachronism in light of a life course increasingly characterized by multiple transitions.

Susan McDaniel picks up this thread and offers a new concept as a guidepost to capture the dynamic shift of individuals in and out of the family, the labour market, and government programs across the life span and across generations. She introduces the concept of "the life cycle of dependencies and responsibilities" which taps the shifting terrain of caring and sharing at the individual and generational level. Applying the concept at the micro level, the private and-public become visible because the dependencies and responsibilities in each domain are detailed. At the macro level, intergenerational differences in life cycle dependencies and responsibilities also become evident, along with a simultaneous consideration of the past, the present and the future. Like Guillemard, she calls for changes in social policy to link labour market and aging policy and to reflect the dependencies and responsibilities across the life course and across generations.

Together, these two papers foretell a development that seems to be emerging both internationally and abroad - the feminization of work. Contrary to the prevailing wisdom that the careers of the baby boom women will look more like men's, the opposite seems to be unfolding. The work 
trajectory for men is starting to look more like the work trajectory for women. Men at both ends of the age spectrum move in and out of the labour force due to high levels of unemployment, and in accordance with a series of jobs that are frequently nonstandard. While more women than men work part-time, more men than women hold temporary jobs. Average wages and earnings have become stagnant, and men are less likely to be covered by an occupational pension than they were ten years ago. The likelihood of men going back to work after retirement appears to be on the rise with the transition between work and retirement becoming blurred. Sounds familiar!

As Guillemard suggests, we need to reevaluate the social transfers associated with retirement. Transfer payments should not be a function of age but of needs as they arise across the life course. McDaniel concludes that realistic policies will only be formulated if they are predicated on analyses of people as they live in their families, within a generational and historical context. These ideas have considerable potential if the feminization of work grows, but even if it doesn't, these work patterns still represent the lives of women, which are not recognized in pension policy. The question then is why do policy-makers persist in making policy according to an orderly life course of education, work, and retirement founded on the experience of the 19th century male industrial worker? Why are the changes in the life course being ignored? Why is social policy still being forged on an ad hoc basis? Why do we attempt to build social policy one generation at a time?

Frank Denton and Byron Spencer provide evidence that the demographic apocalypse will not occur as a result of the aging of the baby boomers; rather, with careful reallocation of resources among expenditure categories and with long-term planning, the overall expected increases in social costs should be manageable. The authors examine four alternative measures of the "cost" of population aging: the traditional dependency ratio; a weighted dependency in which older and younger groups are weighted differentially; projected public expenditures on older and younger dependents; and projected public expenditures as a percentage of the gross national product. They argue that we need to take the long view in designing health care as an integrated system and, because health care is not determined by market forces, it is the governments' responsibility to provide the leadership. Because the cost of social security is partially determined by who is defined as old, Denton and Spencer advance the possibility of raising the age of eligibility for pensions to reflect increases in life expectancy, taking into account the fact that mandatory retirement at age 65 would also have to be altered.

Robert Brown addresses the issues of population aging from a different angle. The apocalyptic demography rhetoric has caused quite a stir about the viability of "paygo" 2 pension schemes in many western nations. He carefully weighs the pros and cons of the Canada/Quebec Pension Plan, a paygo plan, in comparison to an alternative, a pre-funded scheme such as 
the Chilean model. He concludes in favour of the paygo scheme and critically dissects how the controversial "Super RRSP" would play out in terms of assuring security of income in old age. Among other things, there would be no income redistribution in the plan, a characteristic that is incompatible with a moral economy predicated on use value, and one Canadians seem to want (Peters, 1995). Overall, the results of his assessment are less than encouraging and he wonders out loud why the "Super RRSP" manages to have supporters. If Brown is wondering, so should everybody else, especially in light of the recent Bre-X fiasco. Placing security for retirement income in the hands of professional money managers for investment in private-sector assets is a little unsettling in these strange times. He then argues for the raising of the age of retirement, not to reduce the costs of public pensions per se, but to solve what he calls the wealth transfer dilemma, i.e. the transfer of wealth to educate and provide health care to the young will be less than the transfer of wealth required for the health care and pensions of older persons, making for an unstable economy.

Raising the age of retirement could be positive for many people - workers who are forced to retire before their time, workers who feel useless, employers who would retain experienced labour and taxpayers because the costs of public pensions would be eased and contributions to the C/QPP would be lowered. It is not a bad plan if the more vulnerable, like the unhealthy and poor, are protected by special provisions. So why aren't governments discussing this possibility? Ken Battle, who argues that raising the age of retirement is regressive, notes in his paper that An Information Paper for Consultations on the Canada Pension Plan (Federal and Provincial Governments, 1996) does not offer a full range of options to reform the C/QPP because certain options have already been precluded. The real discussion of alternatives will be held behind closed doors between the federal and provincial governments. It would be interesting to know what options have been precluded, who precluded them and on what grounds and, better still, why the public is excluded from the discussion.

The research of Denton and Spencer into reallocating program expenditures and Brown's analysis of funding schemes, together raise the least popular question of all - what about reducing tax expenditures on RRSPs and on RRPs? We seem to studiously ignore that money spent through foregone revenues from the tax system is government spending just like money spent on social programs. About $\$ 15$ billion dollars (Shillington, 1996) could be saved by eliminating these expenditures which are really a form of welfare by stealth for the better-off, to para-phrase Battle. The argument that we need investment capital is starting to wear thin given there is actually a surplus (Brown, this issue).

Battle's article recounts the history of pension change in Canada, culminating in a critical analysis of the New Seniors Benefit and the changes in store for the C/QPP. In the process, he makes some disconcerting observations. During the "Great Pension Debate" of the early 1980s, there was substantial discussion with all constituencies included, especially the pub- 
lic. As Battle notes, however, there was a lot of talk and little action. Today, there is a lot of action and little talk, the central concern of this editorial. Battle himself points out how his proposal for pension reform, which is the foundation for the Seniors Benefit, has garnered little comment except amongst a small group of social policy analysts, and a few national groups (National Advisory Council on Aging, 1996; National Council of Welfare, 1996). Part of the problem, as he sees it, is the strategy of implementation that the government employed - the Benefit was presented as a "done deal" calculated to quell opposition by "grandparenting" current seniors.

He outlines some of the changes, anticipated in the Brown article, that are likely to surface in the changes to the C/QPP, all of which are fairly unpalatable - partial funding, increases in contribution rates, and the trimming of benefits. If there are any uncertainties about the devastating effect many of these changes will have, my paper on retired widows quickly puts these doubts to rest. As the saying goes, women are one husband away from poverty. The analysis shows that 49 per cent of retired widows live below the poverty line and they have the lowest income when compared to the married, separated/divorced and ever single women. The findings cannot be dismissed as a cohort effect with the usual argument that women will have their own pensions in the future. Less than one-half of women have their own occupational pensions today and women's intermittent and part-time work patterns in low paying jobs show few signs of change.

I agree with Battle that there are many aspects of the Seniors Benefit that are controversial but few aging experts seem to have entered the discussion. However, every paper in this issue indirectly points to serious flaws with the Seniors Benefit. To begin with, the Benefit represents a change to a social program when perhaps some other form of cost reduction could have been considered (Battle). Still on the program side of the equation, were other expenditure categories even considered (Denton and Spencer)? The Benefit does not reflect a changing life course full of multiple transitions at varying points in time (Guillemard). Age 65 is still the entitlement age with no apparent flexibility in the program; returning to work after retirement, even part-time, will carry economic penalties. If the pattern of employment continues to move in the direction of more nonstandard work, it is very likely that future generations will depend very heavily on the Seniors Benefit. The catch is that the Benefit, an example of a half-hearted measure, does not move poor seniors over the low income cut-offs established by Statistics Canada (McDonald).

The Benefit explicitly ignores the caring and sharing of current and future generations and the intertwining of work and the family (McDaniel, Brown). In this regard, the Benefit, as family income-tested, represents what Margrit Eichler calls familism, and familism is part of the sexist syndrome. The Seniors Benefit treats the family "... as the smallest unit of analysis in cases where it is, in fact, individuals within families ... that engage in certain actions, have certain experiences, suffer or profit from particular costs or benefits" (Eichler, 1997, p. 90). Every gerontologist 
knows that women's caregiving behaviour at different times in the life course negatively affects their careers, pensions, and ultimately their income in retirement. With the Benefit, their reward for performing an essential societal function is basically no pension of their own, and/or not much of a pension, because it will be based on their husband's income (usually the higher income in a family and the one to be used in the calculations of the Benefit). It is further proposed that the amount of the Benefit will be divided equally between two cheques to be issued separately to the husband and wife, a form of token recognition that women have made a contribution to society. The question is, why don't women receive direct recognition for their substantial contributions, not only to the family, but also to the Canadian economy like men do? This raises another interesting question as to why the RRSP ceiling, and therefore the benefits, apply to individual earnings and contributions, and not to family earnings (Shillington, 1995). Why should the Benefit be different?

There are, of course, many more questions and counter questions to be found in the articles, but the point remains - questions have to be asked and answers critically analysed. We genuinely require another "Great Pension Debate," one that includes gerontologists, not just policy analysts, and experts from the financial community. So, to end on the most politically out-of-the-question, question, we have to ask ourselves, "Why are we not involved?".

\section{Notes}

1 I would like to thank Louise Plouffe for co-chairing the symposium, Re-Writing Social Policy for an Aging Society, and for her outstanding support of the Canadian Association on Gerontology.

2 Authors describe these schemes in various ways; elsewhere in this volume the terms "pay-as-you-go" and "pay-go" pension schemes are used.

\section{References}

Eichler, M. (1997). Family shifts: Families, policies, and gender equality. Toronto: Oxford University Press.

Federal and Provincial Governments. (1996). An information paper for consultations on the Canada Pension Plan. Ottawa.

Freeman, R.B. (1995). W(h)ither the welfare state in an epoch of rising inequality? In K. Banting \& C.M. Beach (Eds.), Labour market polarization and social policy reform. Kingston: School of Social Policy Studies, Queen's University.

Hendricks, J., \& Leedham, C.A. (1991). Political economy of aging. In M. Minkler \& C.L. Estes (Eds.), Critical perspectives on aging: The political and moral economy of growing old. Amityville, NY: Baywood Pub. Co., Inc.

National Advisory Council on Aging. (1996). The National Advisory Council on Aging brief on the five principles for federal pension reform.

National Council of Welfare. (1996). A guide to the proposed seniors benefit. Ottawa: Minister of Supply and Services Canada.

Osberg, L., \& Fortin, P. (Eds.). (1996). Unnecessary debts. Toronto: James Lorimer and Co. 
Peters, S. (1995). Exploring Canadian values: A synthesis report. Ottawa: Canadian Policy Research Networks, Inc.

Saul, J.R. (1995). The unconcious civilization. Concord, ON: House of Anansi Press Ltd.

Shillington, R. (1995). The targetting paradox. Insight. Ottawa: Canadian Council on Social Development.

Shillington, R. (1996). The tax system and social policy reform. In J. Pulkingham \& G. Ternowetsky (Eds.), Remaking Canadian social policy: Social security in the late 1990s (pp. 100-111). Halifax: Fernwood Pub.

Stone, D.A. (1984). The disabled state. Philadelphia: Temple University.

Van Audenrode, M. (1996). Some myths about monetary policy. In L. Osberg \& P. Fortin (Eds.), Unnecessary debts. Toronto: James Lorimer and Co.

Lynn McDonald 